\section{Sixth nerve palsy in nasopharyngeal carcinoma}

Jane W. Chan, MD, Las Vegas, NV

A 45-year-old man who had a 12 pack-year smoking history presented with a 7-month history of headaches and acute horizontal diplopia and dizziness. Examination revealed only a complete right abduction deficit. After undergoing neoadjuvant chemotherapy followed by concurrent chemoradiotherapy, his diplopia resolved.

He developed an isolated sixth nerve palsy, a rare neuroophthalmologic presentation for this tumor. Only one other case has noted an isolated sixth nerve palsy. ${ }^{1}$ Another showed optic nerve involvement as the only presenting sign. ${ }^{2}$ Perineural invasion of this cranial nerve remained clinically silent when its spread was still confined below the base of the skull. Nasopharyngeal carcinoma should be considered in the differential diagnosis of an isolated, nonprogressive chronic sixth nerve palsy of more than 6 months duration.

1. Savino PJ, Hilliker JK, Casell GH, et al. Chronic sixth nerve palsies. Arch Ophthalmol 1982;100:1442-1444.

2. Prasad U. Cancer of the nasopharynx, a clinical analysis with anatomico-pathological orientation. JR Coll Surg (Edinburgh) 1972;17: 108.
Neuro Images
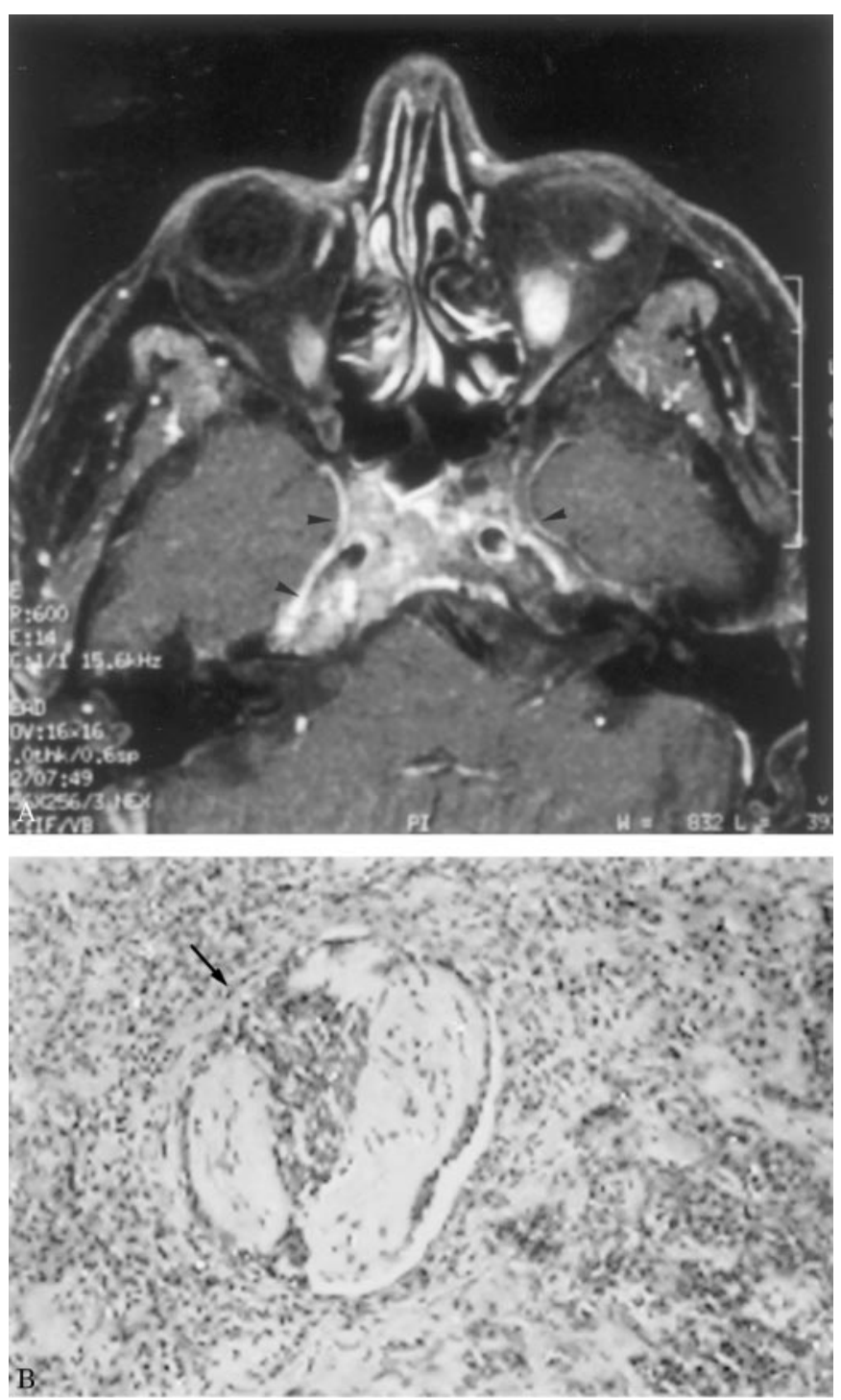

Figure. (A) The nasopharyngeal carcinoma (arrows) is encasing both carotid arteries in the cavernous sinus of this patient, as seen on this coronal view of the MRI of the brain with gadolinium. (B) Histologic cross-section of the right sixth nerve showed perineural invasion (arrow) by a poorly differentiated squamous cell carcinoma of the nonkeratinizing subtype (hematoxylin and eosin, $\times 100$ ).
Address correspondence and reprint requests to Dr. Jane W. Chan, Department of Internal Medicine, Division of Neurology, University of Nevada School of Medicine, 1707 W. Charleston Blvd., Suite 220, Las Vegas, NV 89102; e-mail: worjun@aol.com 


\title{
Neurology
}

\author{
Sixth nerve palsy in nasopharyngeal carcinoma \\ Jane W. Chan \\ Neurology 2003;61;1417 \\ DOI 10.1212/01.WNL.0000090567.33686.A3
}

This information is current as of November 24, 2003

\section{Updated Information \&} Services

References

Citations

Permissions \& Licensing

Reprints including high resolution figures, can be found at: http://n.neurology.org/content/61/10/1417.full

This article cites 2 articles, 0 of which you can access for free at: http://n.neurology.org/content/61/10/1417.full\#ref-list-1

This article has been cited by 1 HighWire-hosted articles: http://n.neurology.org/content/61/10/1417.full\#\#otherarticles

Information about reproducing this article in parts (figures,tables) or in its entirety can be found online at:

http://www.neurology.org/about/about_the_journal\#permissions

Information about ordering reprints can be found online:

http://n.neurology.org/subscribers/advertise

Neurology ${ }^{\circledR}$ is the official journal of the American Academy of Neurology. Published continuously since 1951, it is now a weekly with 48 issues per year. Copyright . All rights reserved. Print ISSN: 0028-3878. Online ISSN: 1526-632X.

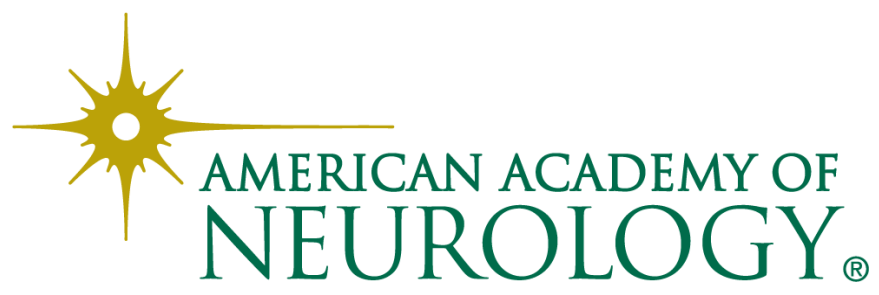

